\section{LIS labour market research: implications for management development}

fohn Cullen

\section{The author}

John Cullen is Senior Management Researcher at the Centre for Management Research, Irish Management Institute, Dublin, Ireland.

\section{Keywords}

Labour market, Libraries, Management culture,

Management development, Leadership,

Continuing professional development

\section{Abstract}

Research findings on the recruitment market for library and information service (LIS) workers are discussed in the context of management development. Qualitative and quantitative analysis of the results uncovered implications for organisations and individuals seeking to develop management and leadership capabilities amongst managers of library and information services. Recruitment advertising seems to solicit applications for management positions on the grounds of evidence of professional development rather than evidence of management development. The implications of professional and management cultures for library management and leadership development are discussed. Further research questions on management development in a library setting are proposed.

\section{Electronic access}

The Emerald Research Register for this journal is available at www.emeraldinsight.com/researchregister

The current issue and full text archive of this journal is available at

www.emeraldinsight.com/0143-5124.htm

Library Management

Volume $25 \cdot$ Number $3 \cdot 2004 \cdot$ pp. 138-145

(C) Emerald Group Publishing Limited · ISSN 0143-5124

DOI 10.1108/01435120410522352

\section{Introduction}

This paper discusses implications for management development in a library and information service context. Findings from research that collected and analysed data on the library and information management recruitment market in Ireland over a one-year time period provided an empirical framework for reflecting the needs of employers for potential library and information service managers. The collection and analysis of employment notices and related documentation have long proved a useful methodology in revealing the skills, competencies and qualifications required by employers (Moore, 1987; Apostle and Raymond, 1991; Palmer, 1992; Willard and Mychalyn, 1998; Cullen, 2000, 2002; Tice, 2001). Cote (1989) has stated:

Job postings reflect the changes in our information world. A number of studies based on job advertisements have been conducted in recent years.

Recruitment advertising and associated documentation for potential applicants for positions provides a uniquely rich perspective on a given sector of a labour market, because it bluntly states necessary and desired employer requirements from candidates. Recruitment advertising is how the employment market communicates its needs to individuals seeking to engage with it.

Funding was provided by the 2001 Library and Information Research Group/Elsevier Research Award for a research project to capture and analyse data on employment for library and information management workers in Ireland over a 12-month period.

The aims of the project were to report on the library and information management market by demonstrating:

- the number of positions available;

- trends in the dissemination of employment vacancy information;

Received 11 July 2003

Revised 6 September 2003

Accepted 28 September 2003

The author wishes to express his sincere gratitude to the Library and Information Research Group for making this programme of research possible through the LIRG/Elsevier Research Award 2001. 
- trends in times of job availability;

- positions available;

- where positions were available;

- $\quad$ salary ranges on offer;

- $\quad$ specific skills sought by employers; and

- levels of experience and professional qualifications required.

The research also investigated "emerging" information labour market positions, described by Willard and Mychalyn (1998) as the:

... broad range of information management positions which are not part of the established LIS field or the information-handling component of other established occupations and which fitted, in the researchers' assessment, the criterion that the tasks were appropriate ones for LIS graduates.

This paper reviews the positions identified, which applied to management positions only, in order to ascertain the skills, competencies, levels and types of experience and qualifications which employers sought in potential candidates for employment. The paper presents quantitative findings on these requirements in general. It also presents qualitative data on requirements for managers at supervisory, middle and senior management positions.

\section{Management development}

Management development is ... a multi-faceted process, in which some aspects are easier to identify and measure than others (Thompson et al., 2001).

The field of management development is becoming increasingly complex and fragmented (Holman, 2000), yet remains an issue of key strategic importance to organisations (Worrall and Cooper, 2001; Michaels et al., 2001). Concerns have been raised about the role of the higher education institution in the development of the manager (Boyatzis, 2000; Monks and Walsh, 2001). The difference between management education and management development has been defined as follows:

Management education tends to be more theoretical, emphasising a body of knowledge, whereas management development tends to be more practical, emphasising a repertoire of skills - in Quinn's (1992) terms: "know-what" and "know-why" in contrast with "know-how" (Fox, 1997).
There is evidence that management development is more appropriately concerned with development of experiential knowledge as opposed to formal/theoretical knowledge:

It is experiential liberalism and the experiential/critical school that appear to offer the greatest potential for developing managers. The evidence marshalled ... suggests that their experiential pedagogies do go a long way to promote learning and development (Holman, 2000).

Despite this, a number of surveys have been carried out to discover exactly what it is that makes a good manager:

The conclusion to be drawn from these surveys is that certain personality attributes are necessary in a competent manager, that experience is still a key dimension, but that development of various types makes a significant if not overriding contribution to management competence (Thompson et al., 2001).

There are a number of management development models in practice, and since the 1990s there have been attempts to develop models which allow for the various types which are appropriate to differing forms of organisation and individuals' learning styles.

\section{Methodology}

A news-monitoring agency was employed to scan for, and obtain, advertisements for library and information work from the start of April 2001 to the end of March 2002. The agency was provided with a "family" of 45 sample job titles which had been identified in an earlier Irish LIS labour market research project (Cullen, 2000). Relevant Web sites and mailing lists were regularly checked and exploited to ensure that the optimum level of sources was utilised for collecting data sources.

When the employment notices were received, supplementary data such as employment details, job descriptions, application forms, etc. were requested and included in the analysis in order to obtain the widest possible range of recruitment data.

The content of these documents was analysed and recorded in some 120 fields. In this paper, general results on management skills captured 
in the project database are reported. This is followed by a qualitative analysis of the management development needs, as observed in the documentation for senior, middle and supervisory managers. The method for selecting advertisements for qualitative review reflects that of Communal and Senior (1999). In their analysis of cultural differences in a management context, they collected advertisements for management appointments from three publications, numbered the first 100 advertisements and randomly selected ten for each culture under analysis. In this paper reference will be made to sector-specific requirements where relevant. Qualitative analysis will report on content inside the following frames:

- required formal development of managers;

- required experiential development of managers;

- management knowledge required/desired;

- management competencies required/desired; and

- personal and interpersonal skills required/desired.

\section{Overall results for managers in library and information services}

The findings of the project have been reported in broader terms elsewhere (Cullen, 2002). In total 301 advertisements for 323 positions were sourced. Of these, 82 positions (27.4 per cent) required management skills. However, when these positions are analysed by job-title as appeared in the job advertisement, 65 or 20 per cent were advertised as supervisory or managerial positions. This indicates that requirements for management capabilities do not necessarily appear on the initial point of contact for potential library or information service managers (the job advertisement). The specific management skills which were sought by employers are outlined in Table I.

Additionally, single mentions were made of the following management skills and attributes: managing task-based work, policy formulation, project development, responsibility, prioritisation, change management, service promotion, managing complexity, initiating and
Table I Required management skills

\begin{tabular}{lc}
\hline Management skills identified & No. of cases \\
\hline Administrative/organisational skills & 28 \\
Staff management/supervision & 25 \\
Leadership & 13 \\
Analytical skills/judgement & 13 \\
Project management & 9 \\
Staff training and development & 8 \\
Management skills (general) & 8 \\
Problem solving & 8 \\
Information management & 6 \\
Planning general & 5 \\
Motivation & 4 \\
Strategic planning & 3 \\
Finance/budget management & 3 \\
Evaluation & 2 \\
Reporting & 2 \\
Team building & 2 \\
Service development & 2 \\
\hline
\end{tabular}

developing, facilitation skills, decision making, and co-ordination.

If these findings are viewed in the context of Mintzberg's managerial roles (1973), which categorise management roles as interpersonal, informational and decisional, some interesting results emerge. Disregarding the general

headings of administrative/organisational skills, project management and general management, the majority of mentions are for interpersonal roles (54), followed by decisional roles (31). It is interesting to note that there were only eight mentions of informational managerial role requirements.

Although interesting, these statements of management aptitudes required by employers do not contribute to a richer understanding of how managers should be developed, or should develop themselves, with a view to equipping themselves for progressing through their managerial career. For example, "decision making" is a central function of any managerial role, but the quantitative analysis only found one specific mention of it in the all the documentation obtained. This does not mean that decision making is not a requirement of managers in libraries and information services; in fact it is more likely that it is considered a "given" element of any manager's work. Qualitative analyses of the recruitment documentation relating to managers at senior, 
middle and supervisory levels are provided below. Robbins and Coulter (2002) delineate the difference between these management levels as follows:

First line managers are the lowest level of management and manage the work of non-managerial individuals who are involved with the production or creation of an organization's products. They're often called supervisors ... Middle managers include all levels of management between the first-line level and the top level of the organization. These managers manage the work of first-line managers ... At or near the top of the organization are the top managers, who are responsible for making organization-wide decisions and establishing the plans and goals that affect the entire organization.

In total, ten sets of documentation relative to each management category were selected for qualitative review, as reported in the methodology section above. Of the senior management positions chosen, nine were in traditional library services; two of these were for senior management positions in government department libraries; one for a regional health library service; two for heads of academic library services; two for heads of county public library services; one for head of a county/city library archive service; and one for head of library and information services in a professional membership organisation. The single senior management position in the emerging market chosen for qualitative analysis was for a position as national co-ordinator of a voluntary sector information service.

A more representative division was possible amongst the middle management positions chosen for qualitative review: five were selected from the traditional library services recruitment market, and five from the emerging market; three of the traditional middle management positions were in academic libraries; and two in public libraries. All five emerging market middle management positions were sourced from organisations operating in the voluntary/community sector.

All of the supervisory management positions were sourced from the traditional library sector and all were for senior library assistant positions; six were in public libraries, three in academic libraries and one in a health library service.

\section{Senior LIS managers}

Although most of the recruitment documentation relevant to senior positions sought evidence of experiential knowledge, most of these required LIS or "relevant work experience" rather than management experience, despite the management role involved. Only two of the positions subjected to qualitative analysis sought evidence of experience as a manager or a leader. Little evidence was sought as to specific knowledge areas relevant to management. It is interesting to note that three of the ten senior management positions analysed qualitatively sought evidence of knowledge of administration as opposed to management or leadership. All of the positions sought an individual who would develop the service they were charged with managing, but only one position sought a manager who had knowledge of strategic planning and evaluation. It was also rare for specific competencies to be stated, other than "excellent management or organisational skills" (mentioned in three cases). Half of the positions, however, stipulated requirements for strong communication or interpersonal skills.

\section{Middle managers in library/information services}

Although no formal management development was stated as a requirement in the documentation relating to middle managers, much more information regarding the specific management elements of each specific role was available. As these roles generally involved the management of a department, specialist unit or programme, a level of specificity was most likely needed to ensure that appropriate candidates could be isolated. This was reflected in the fact that all of the positions called for strong experiential management knowledge in the areas of staff supervision and management and very high levels of interpersonal and communication skills, particularly the ability to liaise at all levels and on a cross-departmental and even a cross-agency basis. Areas of specific management knowledge were also widely stated: including strategy, project management (particularly IT projects) and promotional 
abilities. Management skills and competencies were also more likely to be stated for middle managers than for senior managers. These included judgement, flexibility and initiative.

\section{Supervisory managers in library/ information services}

As stated above, all of the supervisory management positions were for senior library assistants. Unlike senior and middle managers, these did not require professional library (or other related) qualifications. In two cases no qualification was stipulated, and a schoolleaving qualification was required for the remainder. At least two years' library work experiences and knowledge of library systems was a requirement in most cases, particularly in the public library sector. Perhaps surprisingly, the supervision of staff was not identified as a requirement in the majority of the cases which were reviewed qualitatively, but training of staff was mentioned more often as a requirement of the senior library assistant role. Strong IT competencies were ubiquitous requirements amongst all recruitment documentation relevant to senior library assistant positions.

\section{Implications for library management development}

From these results it appears that the richest data on management development issues in the LIS sector are obtainable through documentation relevant to middle management positions. Studies of organisational cultures (e.g. Turnbull, 2001; Currie, 1998)

increasingly tend to focus on middle managers who are effectively gatekeepers to the success of organisational change initiatives. Because of the key role that middle managers play in facilitating change in services, it may be the case that it is of central importance that middle managers in libraries and information services are required to be best equipped to flexibly meet the changing needs of external and internal customers and service users. This is not to say that skills are not needed for senior management or supervisory posts; in the case of senior managers, the dearth of information on the specifics of the post may point to the highly generalised nature and responsibilities associated with the positions, or may indicate that employers feel the senior managers have been sufficiently developed by their experiences during the time they spent as middle managers. Handy et al. (1988) state:

Managerial abilities and competences are best developed from experience. This does not, however, happen automatically. The experience has to be reflected upon, understood and subsequently improved upon if there is to be any true learning beyond the crude "I won't do that again". The experience, moreover, needs to be of more than one type; the reflection needs to be organized and assisted in some way, the scope for improvement needs to be stimulated by opportunities to examine how others do it and, finally, there has to be enough scope for the individual to try out possible improvements and enough tolerance to overlook the occasional mistake in pursuit of improvement.

If it is the case that managers are best developed by experience, but in the context of a management development programme, it is perhaps useful to briefly examine how librarians are expected to develop as professionals. Entry into professional library positions in "traditional" academic and public library services is heavily dependent on professional qualifications. The research found that in all the professional librarian positions in academic and public libraries a professional qualification in library and information studies was the key, essential qualification for entry. The only exception to this was a part-time, contract position for which the recruiters stated that such a qualification would be advantageous, rather than essential.

The finding that professional qualifications are essential requirements for applicants for both managerial and professional roles is significant because it signposts possible avenues for developing managers in libraries and information services.

Schein (1996) identified three particular cultures in any organisational culture:

Every culture develops an internal culture based on its operational success, what I call the "operator culture". But every organization also has, in its various functions, the designers and technocrats who drive the core technologies. I call this the "engineering culture"; their fundamental reference 
group is their world-wide occupational community. Every organization also has its executive management, the CEO and his or her immediate subordinates - what I call the "executive culture".

It is more accurate to describe librarians as being part of a professional culture; relevant experience is obtained, a professional graduate course is completed and individual members of the professional culture then embark on developing their professional skills, experience and profiles in various ways.

The issue is that library managers are developed and recruited as professionals, but at a management level they must also exist and perform as part of the executive/management culture despite having not been developed to do this. It is our tradition to refer to the senior management position in a public or academic library service as a professional ("the" librarian) rather than as a manager. This embeds the role of the library manager in the professional rather than the managerial culture of the organisation. These cultures have different assumptions and values and Schein has pointed out how the lack of understanding about their very nature and how they interact has led to the emergence of work situations which are often highly dangerous:

Until executives, engineers, operators discover that they use different languages and make different assumptions about what is important, and until they learn to treat the other cultures as valid and normal, organizational learning efforts will continue to fail (Schein, 1996).

Librarians are trained to utilise their information-handling and organising expertise to maximise the benefit of available resources for their users. A responsible service ethic is embedded in the culture of the professional librarian. Executive/management cultures:

... focus on financial survival and growth to ensure returns to shareholder and to society (Schein, 1996).

Organisational sub-culture clashes are bound to emerge. The site of this tension is the role of the librarian working in a management position, who must choose a culture with which they must align. Management development programmes for librarians should recognise the difference between these cultures and pay close attention to the organisational sub-cultural tensions which arise from these issues.
Although the research found that evidence of post-qualification management/leadership development is not perceived as a priority for recruiters, the fact that "leadership" competencies and skills were the third most sought-after requirement for recruiting organisations points to a change in the way in which parent organisations view their library services and the management of these services. The UK Government-appointed Council for Excellence in Management and Leadership (2002) identify leadership skills as:

... those skills which relate to: creating a sense of vision in a fast-changing environment; motivating teams of people and leading them through change; and being innovative in products and services and ways of working.

Global economic fluctuations and societal change affect the needs of users of library and information services regardless of the sector in which they operate. This is particularly true in an Irish context:

In the contemporary world, it would be difficult to find an example of such deep, intense and rapid transformation as has occurred in Ireland (Peillon, 2002).

There is no doubt that change has become a constant in all societies and this has had a profound impact on library and information workers. Cross-sectoral library research by the Irish Library Council, An Chomhairle Leabharlanna (1999), found that 75 per cent of respondents believed that the roles of library and information staff had changed over the preceding three years, primarily in the area of dealing with new technology. Professional training focuses on delivering information professionals equipped with the most up-to-date skills. Leadership training equips those responsible for the management of these professionals to lead them through change:

The word management suggests custodianship, even control, and a concentration on managing resources that already exist. A better term is knowledge leadership. In contrast to management, "leadership" is about constant development and innovation - of information resources, of individual skills (an important part of the knowledge resource) and of knowledge and learning networks. It embraces both the sharing of what is known and innovation - the two thrusts of a knowledge-enhanced strategy (Skyrme, 2000). 


\section{Conclusions}

To suggest that separate qualifications be developed for librarians and library managers would exacerbate the problem of the clash between professional and management cultures. Formalised management development programmes for professional librarians are a step towards ensuring that managers in library and information service settings do not become isolated from the management culture in an organisation at management team level. More importantly, it offers an opportunity to enable library managers both to protect and to develop services as key strategic resources for parent organisations by developing understanding of the priorities of executive/management cultures and how to lead services during times of fundamental socio-economic change.

Some obvious limitations of the research is that recruitment documentation is often produced to meet certain legal and organisational criteria, and it is highly likely that appointee selection happens during candidate interviews. Other limitations are the confines of the data collection of the project which took place in one national context inside a single 12-month timeframe. To explore the issue of management and leadership development in a library context a set of research questions needs to be developed and it is suggested that these should include the following:

- What do managers in libraries perceive as their management/leadership development needs?

- What are the management development needs as identified by employers?

- What are the features of successful library managers/leaders who achieve in their professional and executive cultures?

- What models of management development are most appropriate to managers of library and information services?

\section{References}

An Chomhairle Leabharlanna (1999), Joining Forces: Delivering Libraries and Information Services in the Information Age, An Chomhairle Leabharlanna, Dublin.

Apostle, B. and Raymond, R. (1991), "Library and information work in Canada: further analysis of an emerging labour market", The Canadian Journal of Information Science, Vol. 16 No. 2, pp. 40-51.

Boyatzis, R.E. (2000), "Management education: coming of age", Selections, Vol. 16 No. 2, pp. 14-15.

Communal, C. and Senior, B. (1999), "National culture and management: messages conveyed by British, French and German advertisements for managerial appointments", Leadership \& Organization Development Journal, Vol. 20 No. 1, pp. 26-35.

Cote, C. (1989), "The library job market as seen from Quebec", Canadian Library Journal, Vol. 46 No. 3, pp. 165-7.

Council for Excellence in Management and Leadership (2002), Managers and Leaders: Raising Our Game, Council for Excellence in Management and Leadership, London.

Cullen, J. (2000), "A review of library and information service job advertisement: what do they tell us about work in the Irish library sector?", Journal of Information Science, Vol. 26 No. 4, pp. 278-81.

Cullen, J. (2002), "The employment market for library and information management workers in Ireland", Library and Information Research News (LIRN), Vol. 26 No. 3, pp. 17-26.

Currie, G. (1998), "Stakeholders' views of management development as a cultural change process in the health service", International Journal of Public Sector Management, Vol. 11 No. 1, pp. 7-26.

Fox, S. (1997), "From management education and development to the study of management learning", in Burgoyne, J. and Reynolds, M. (Eds), Management Learning: Integrating Perspectives in Theory and Practice, Sage, London.

Handy, C., Gordon, C., Gow, I. and Randlesom, C. (1988), The Making of Managers, Pitman Publishing, London.

Holman, D. (2000), "Contemporary models of management education in the UK", Management Learning, Vol. 31 No. 2, pp. 197-217.

Michaels, E., Handfield-Jones, H. and Axelrod, B. (2001), The War for Talent, Harvard Business School Press, Boston, MA.

Mintzberg, H. (1973), The Nature of Managerial Work, Harper \& Row, New York, NY.

Monks, K. and Walsh, J.S. (2001), "The role of postgraduate education in management development", Journal of European Industrial Training, Vol. 25 No. 2-4, pp. 148-56.

Moore, N. (1987), The Emerging Markets for Librarians and Information Workers: Library and Information Research Report, The British Library Board, Boston Spa.

Palmer, J.W. (1992), "Job advertisements and cataloguing skills", Journal of Education for Library and Information Science, Vol. 33 No. 1, pp. 61-3.

Peillon, M. (2002), "Introduction", in Peillon, M. and Corcoran, M.P. (Eds), Ireland Unbound: A Turn of the Century Chronicle, IPA, Dublin, pp. 1-12.

Robbins, S.P. and Coulter, M. (2002) Management, Prentice-Hall, Englewood Cliffs, NJ. 
LIS labour market research: implications for management development

John Cullen

Schein, E.H. (1996), "Three cultures of management: the key to organizational learning", Sloan Management Review, Vol. 38 No. 1, pp. 9-20.

Skyrme, D.J. (2000), "Developing a knowledge strategy: from management to leadership", in Morey, D., Maybury, M. and Thuraisingham, B. (Eds), Knowledge Management: Classic and Contemporary Works, MIT Press, London, pp. 61-83.

Thompson, A. et al. (2001), Changing Patterns of Management Development, Blackwell, Oxford.

Tice, B. (2001), "Too many jobs, too few job seekers? A study of law librarianship job data samples
Library Management

Volume $25 \cdot$ Number $3 \cdot 2004 \cdot 138-145$

1989-1999", Law Library Journal, Vol. 93 No. 1, pp. 71-91.

Turnbull, S. (2001), "Corporate ideology - meanings and contradictions for middle managers", British Journal of Management, Vol. 12, pp. 231-42.

Willard, P. and Mychalyn, J. (1998), "New information management work in a changing world: an Australian survey", International Journal of Information Management, Vol. 18 No. 5, pp. 315-27.

Worrall, L. and Cooper, C. (2001), "Management skills development: a perspective on current issues and setting future agenda", Leadership \& Organization Development Journal, Vol. 22 No. 1, pp. 34-9. 